RESIDENT

\& FELLOW

SECTION

Section Editor

Mitchell S.V. Elkind,

MD, MS

\title{
International Education Issues: Neurology and poverty
}

Address correspondence and reprint requests to Dr. Farrah Jasmine Mateen, Mayo Clinic, Rochester, unit \#1, \#7-11th Ave. NW, Rochester, MN 55901

farrah_mateen@hotmail.com
Farrah J. Mateen, MD

Few people in the world today are rich; the vast majority, $86 \%$ of the global population, live in the developing world, in countries that are classified as low or middle income. ${ }^{1}$ The most recent data on extreme poverty suggest that nearly a billion people, spread over many continents, live on less than one dollar per day. ${ }^{2}$ It is in low and middle income (LAMI) countries where most cases of neurologic disease occur, including stroke, epilepsy, primary headache disorders, and Alzheimer disease, ${ }^{3}$ and in these countries neurologic disease is studied little if at all.

The public health challenges for neurologic disorders in LAMI countries are multiple. Among the poor, there is special consideration of the 1) overall burden of neurologic disease, 2) lack of access to essential medications, 3) paucity of epidemiologic research available, 4) reduced ratio of practitioners in LAMI countries, 5) double burden of communicable and noncommunicable disease, and 6) stigma. At every level of society, there is a need for more education, in rich countries as well as poor ones. Health care workers, students, governments, teachers, and members of the general public all have important roles to play.

THE OVERALL BURDEN OF NEUROLOGIC DISEASE Dementia and stroke are among the most common disabling diseases worldwide, ${ }^{4}$ and in some regions of the world, stroke accounts for more deaths than ischemic heart disease. Although often considered developed world diseases, $86 \%$ of all stroke mortality ${ }^{5}$ and $85 \%$ of all cases of epilepsy ${ }^{3}$ occur in the developing world. Overall, neurologic disorders now account for a greater burden of disease than HIV/AIDS. ${ }^{4}$

LACK OF ACCESS TO ESSENTIAL MEDICATIONS Studies from LAMI countries reveal poor access to underprescribed and often unaffordable medications. In one recent analysis ${ }^{6}$ of four low and six middle income countries, just $71.5 \%$ of patients with cerebrovascular disease were taking aspirin. In sub-Saharan African nations, most medications are simply not available in public and private facilities, regardless of a patient's wealth. The World Health Organization (WHO) estimates that 150 countries do not have adequate access to medications to treat pain. ${ }^{3}$

Moreover, 50 to $90 \%$ of people in LAMI countries must pay for their medications entirely by themselves. ${ }^{7}$ In Chad, a 30-day supply of carbamazepine $200 \mathrm{mg}$ twice daily costs the equivalent of 8.8 days of an unskilled government laborer's wages, rendering treatment of a very treatable disease effectively unattainable. ${ }^{8}$ Thus, access to essential medications is a result of both availability and affordability. Although costs and wages are objectively measured, the health-care seeking behavior of the poor is largely unstudied.

PAUCITY OF EPIDEMIOLOGIC DATA AVAILABLE ON NEUROLOGIC DISEASE From a public health stance, there is a lack of research in neurologic disorders. In other medical specialties, high income countries produce more than $90 \%$ of the world's research although they account for approximately $10 \%$ of the global population. This is the so-called $10-90$ divide in medical publication. It is uncertain whether the 10-90 divide exists in the neurologic literature because it has not been formally studied except in the case of dementia. ${ }^{9}$

Among the neurologic disorders, research in LAMI countries has been so limited that their prevalence is difficult to estimate. Unlike census reports and sophisticated database analyses available from high income countries, epidemiologic information from LAMI countries is often obtained via tedious door-to-door surveys and reported in non-indexed, low-impact journals. ${ }^{10}$ Many studies piggyback on cardiovascular disease research and lack an emphasis on neurologic disorders. Little, in fact, is known about the cognitive effects of neuroAIDS outside of industrialized nations. ${ }^{11}$

The value of research publications in LAMI countries also differs. A publication in the devel- 
oping world, even more so than in the developed world, may have little effect on real life practice. ${ }^{12}$ Thus, searches for "neurology," "headache," “dementia," and other common diseases in popular medical databases reveal no articles on neurologic disease, at any point in time, from a number of LAMI countries, accounting for knowledge gaps that encompass millions of people over decades.

REDUCED RATIO OF PRACTITIONERS IN LAMI COUNTRIES Where neurologists are needed most, they are least likely to be found. Although the WHO estimates that one neurologist is needed for a population of 100,000 people, ${ }^{13}$ in Africa, there are an estimated 0.3 neurologists per million. ${ }^{14}$ Many countries see neurologic care provided, if at all, by health care workers with no formal training in neurology. Eleven African countries have no neurologists. ${ }^{15}$ Physicians practicing in countries with the greatest need of neurologic care lack resources, educational opportunities, and health care workers. Some physicians emigrate to countries that can provide these desired resources and opportunities. An estimated 20,000 physicians leave Africa each year, ${ }^{16}$ a region which exemplifies this problem. Compared to the number of physicians who leave, the number of high-income country physicians working in Africa is small.

THE DOUBLE BURDEN OF DISEASE LAMI countries may continue to deal with diseases that have been eradicated or are easily prevented in high-income nations, the so-called double burden of communicable and noncommunicable disease. For example, the last case of locally acquired poliomyelitis occurred in the United States in 1979. Yet needless suffering from poliomyelitis among the poor of Pakistan, Afghanistan, India, and $\mathrm{Ne}$ pal persists, ${ }^{17}$ for both medical and cultural reasons, in a world that has largely moved on.

STIGMA The majority of people with epilepsy, approximately 40 million, do not receive treatment. ${ }^{3}$ It would be wrong to assume that this is simply a financial issue, easily corrected by free medications and more health care workers. Recognition of neurologic disorders, particularly neuropsychiatric manifestations, as disease is long overdue.

Adding insult to injury, neurologic disease, even in the richest nations, in the hallways of the wealthiest institutions, can be stigmatized as incurable or barely treatable. In the developed world, common neurologic disorders are both under-recognized and undertreated. ${ }^{3}$ Not only a matter of science, this is a failure of education as well. The situation is probably worse in LAMI countries. If such stigmata persist, neurologic disorders will remain distant from the priorities of public health and public policy worldwide.

Conceptually, neurologic disease and poverty are connected. The idea that poverty and its consequences-most notably, malnutrition-can lead to poor cognitive ability, poor school performance, and eventual school desertion has been explored for decades. ${ }^{18-20}$ More recently, data from these same countries demonstrate that secondary prevention of neurologic disease in adulthood, such as stroke, is positively influenced by a higher level of education. ${ }^{21}$

Thus, when a neurologic problem is addressed scientifically, it next demands collective action for sustained population-wide health improvement. Although small in scope compared to the burden with which they are faced, a number of agencies, academic groups, and nonprofit organizations have begun the great deal of work required. Solutions occur at multiple levels. In February 2007, the World Health Organization (WHO) and World Federation of Neurology (WFN) addressed the European Parliament, launching Neurological Disorders, Public Health Challenges, ${ }^{3}$ a comprehensive summary of the public health knowledge of neurologic disorders to date. Widespread changes for success include the entrance of women into the health care workforce, a focus on neurology within existing health systems, and the need for better epidemiologic information on which to set future priorities. The WHO calls for a "paradigm shift beyond the current preoccupation with prevention and simple curative interventions to encompass long-term support and chronic disease management."3

Others have responded similarly in magnitude. Among them, the Global Campaign Against Epilepsy, the 10/66 Dementia Research Group, the Global Burden to Reduce the Campaign Against Headache, and the WFN have each made progress. The WFN features an online book, Where there is no neurologist, ${ }^{22}$ which is meant to act as a guide to paramedical professionals in the care of neurologic disease. Many universities actively organize, sponsor, and encourage their staff and students to train abroad for short periods of time. Most journals, including this one, are available to physicians in low income countries at a reduced rate of subscription. Headache clinics and neurology training programs now exist where previously there have been none. In more 
than 100 countries, neurologists and nonneurologists alike participate jointly in alleviating the global burden of neurologic disease.

In the current Resident \& Fellow pages of Neurology ${ }^{\circledR}$, two American physicians recount their experiences studying neurology abroad. Dr. Chad Heatwole, ${ }^{23}$ a neurology resident at the University of Rochester, relates his story teaching neurology at Jagiellonian University in Kraków, Poland. Dr. Porter provides an eye-opening account of the neurologic care in an impoverished Kenyan town. ${ }^{24}$ Together, their stories provide the humanitarian perspective, inarguably the most important reason of all, to aggressively tackle these challenges.

\section{REFERENCES}

1. Calculation based on: World Health Organization. The World Health Report 2003. Geneva: WHO, 2003.

2. Another day, another \$1.08. The Economist. April 28, 2007; 90.

3. World Health Organization. Neurological disorders public health challenges. Switzerland: World Health Organization, 2006.

4. World Health Organization. Burden of disease statistics. Available at: http:/www.who.int/healthinfo/bod/ en/index.html. Accessed June 15, 2007.

5. Strong K, Mathers C, Bonita R. Preventing stroke: saving lives around the world. Lancet Neurol 2007;6:182187.

6. Mendis S, Abegunde D, Yusuf S, et al. WHO study on prevention of Recurrences of Myocardial and StrokE (WHO-PREMISE). Bull World Health Organ 2005;83: $820-828$.

7. Quick JD, Hogerzeil HV, Velasquez G, Rago L. Twenty-five years of essential medicines. Bull World Health Organ 2002;80:913-914.

8. Gelders S, Ewen M, Noguchi N, Laing R. Price, availability and affordability: an international comparison of chronic disease medicines. Background report prepared for the WHO Planning Meeting on the Global Initiative for Treatment of Chronic Diseases Cairo 2005. World Health Organization, Health Action International. Available at: http://www.haiweb.org/
medicineprices/30052006/CHRONICANN.pdf. Accessed June 15, 2007.

9. Prince M. Dementia in developing countries. A consensus statement from the 10/66 dementia research group. Int J Geriatr Psychiatry 2000;1:14-20.

10. Sumathipala A, Siribaddana S, Patel V. Underrepresentation of developing countries in the research literature: ethical issues arising from a survey of five leading medical journals. BMC Med Ethics 2004;5:E5.

11. Power C. NeuroAIDS in West Africa: a full circle. Can J Neurol Sci 2007;34:118-119.

12. Mohebbi MR. Scientific publications and the developing world. Lancet 2006;368:1650.

13. Medina MT, Munsat T, Potera-Sánchez A, et al. Developing a neurology training program in Honduras: A joint project of neurologists in Honduras and the World Federation of Neurology. J Neurol Sci 2007;253: 7-17.

14. Bower JH, Zenebe G. Neurologic services in the nations of Africa. Neurology 2005;64:412-415.

15. Neurology in sub-Saharan Africa: WHO cares? Lancet Neurol 2006;5:637.

16. Leach B, Paluzzi JE. Prescription for healthy development: increasing access to medicines. London, England: Earthscan, 2005; 97.

17. Unpublished data. Global update on poliovirus. Geneva, Switzerland: World Health Organization; June 13, 2007.

18. Latham MC, Cobos F. The effects of malnutrition on intellectual development and learning. Am J Pub Health 1971;61:1307-1324.

19. Brown JL, Politt E. Malnutrition, poverty and intellectual development. Sci Am 1996;274:38-43.

20. Alvarez G. The neurology of poverty. Soc Sci Med 1982;16:945-950.

21. Mendis S, Abegunde D, Yusuf S, et al. WHO study on prevention of Recurrences of Myocardial and StrokE (WHO-PREMISE). Bull World Health Organ 2005;83: 820-828.

22. Birbeck GL. Where there is no neurologist. Available at: http://neurology.msu.edu/downloads/where $\% 20$ there $\% 20$ is $\% 20$ no $\% 20$ neurologist_whole $\% 20$ book. pdf. Accessed July 20, 2007.

23. Heatwole CR. Practicing and teaching international neurology: the Krakow experience. Neurology 2007; 69:1721-1723.

24. Porter A. A perspective on the practice of neurology in northern Kenya. Neurology 2007;69:1719-1720. 


\title{
Neurology
}

\author{
International Education Issues: Neurology and poverty \\ Farrah J. Mateen \\ Neurology 2007;69;1724-1726 \\ DOI 10.1212/01.wnl.0000285099.58127.4b
}

This information is current as of October 22, 2007

Neurology ${ }^{\circledR}$ is the official journal of the American Academy of Neurology. Published continuously since 1951, it is now a weekly with 48 issues per year. Copyright. All rights reserved. Print ISSN: 0028-3878. Online ISSN: 1526-632X.

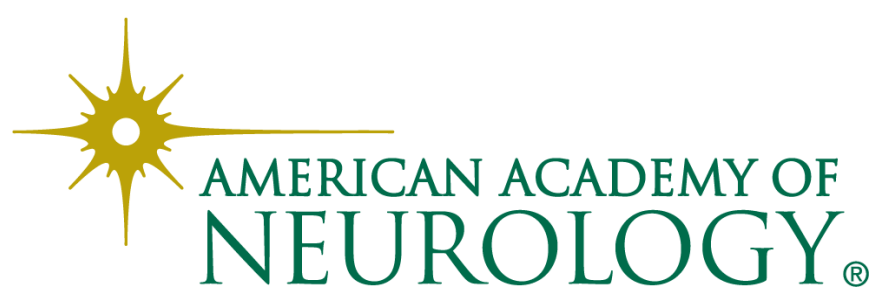




\section{Updated Information \& Services}

References

\section{Subspecialty Collections}

Permissions \& Licensing

\section{Reprints}

including high resolution figures, can be found at: http://n.neurology.org/content/69/17/1724.full

This article cites 16 articles, 3 of which you can access for free at: http://n.neurology.org/content/69/17/1724.full\#ref-list-1

This article, along with others on similar topics, appears in the following collection(s):

\section{Access to care}

http://n.neurology.org/cgi/collection/access_to_care

All Clinical Neurology

http://n.neurology.org/cgi/collection/all_clinical_neurology

All epidemiology

http://n.neurology.org/cgi/collection/all_epidemiology

Burden of disease

http://n.neurology.org/cgi/collection/burden_of_disease

Health systems

http://n.neurology.org/cgi/collection/health_systems

Medical care

http://n.neurology.org/cgi/collection/medical_care

Other Education

http://n.neurology.org/cgi/collection/other_education

Poverty-related disease

http://n.neurology.org/cgi/collection/poverty_related_disease

Underserved populations

http://n.neurology.org/cgi/collection/underserved_populations

Information about reproducing this article in parts (figures,tables) or in its entirety can be found online at:

http://www.neurology.org/about/about_the_journal\#permissions

Information about ordering reprints can be found online:

http://n.neurology.org/subscribers/advertise

Neurology ${ }^{\circledR}$ is the official journal of the American Academy of Neurology. Published continuously since 1951, it is now a weekly with 48 issues per year. Copyright. All rights reserved. Print ISSN: 0028-3878. Online ISSN: 1526-632X.

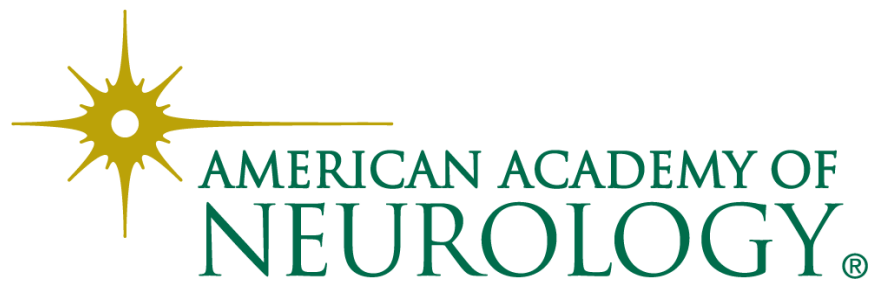

